\title{
The Mixture Of Distribution Hypothesis And The Russian Stock Market
}

Giorgio Canarella (E-mail: gcanare@calstatela.edu), California State University, Los Angeles Stephen K. Pollard(E-mail: spollar2@calstatela.edu), California State University, Los Angeles

\begin{abstract}
According to the mixture of distributions hypothesis $(\mathrm{MDH})$, a serially correlated mixture of variables measuring the rate at which information arrives to the market explains the GARCH effects in stock returns. While reasonable amount of empirical evidence supports this hypothesis for developed, highly liquid stock markets in industrial countries, the current literature does not provide much findings for stock markets in countries that have recently experienced the transition from economic planning to capitalism. Hence, the purpose of this paper is to provide a first piece of evidence for one of the newly created stock market, the Russian stock market. Examination of the relationship between risk, returns, volatility and volume existing in the Russian stock market provides evidence in support of the MDH and suggests that even in emerging and turbulent markets risk and returns are jointly integrated to the flow of information arriving to the market.
\end{abstract}

\section{Introduction}

Much of the recent interest in econometrics and empirical finance has centered on modeling the temporal variation in financial markets' volatility. Particularly instrumental to these developments has been the autoregressive conditional heteroskedasticity (ARCH) model introduced by Engle (1982) and the extension by Bollerslev (1986) to its generalized version $(\mathrm{GARCH})$. There is overwhelming evidence of temporal variation in conditional variability of asset returns in industrialized Western economies. Bollerslev, Chou and Kroner, (1992) survey the empirical evidence that shows that this class of models is able to capture many empirical regularities of asset returns, such as thick tails of unconditional distributions, volatility clustering, negative correlation between lagged returns and conditional variance, and positive relation between expected returns and their conditional volatility.

One hypothesis that has been fairly successful in explaining the success of the GARCH class of models has been the mixture of distributions hypothesis (MDH) (Clark, 1973, Epps and Epps, 1976, Tauchen and Pitts, 1983, Lamoureux and Lastrapes, 1990). According to the MDH, a serially correlated mixing variable measuring the rate at which information arrives to the market explains the GARCH effects in asset returns. This linkage has been documented, among others, for the US stock market (Lamoureux and Lastrapes, 1990, Kim and Kon, 1994, Gallo and Pacini, 2000), the UK stock market (Omran and McKenzie, 2000), and the Australian stock market (Brailsford, 1996). In general the bulk of the empirical studies have found support that the inclusion of trading volume in GARCH models for stock returns results in a decrease of volatility persistence or even causes it to become insignificant. However, while there is a fair amount of empirical evidence on the relationship between returns, volume and volatility for well developed stock markets, the current literature does not provide, with the exception of Bohl and Henke's (2002) analysis of a group of Polish stocks, much empirical findings on this issue for emerging markets, and in particular for markets in transition economies.

The purpose of this paper is to provide some empirical evidence on the issue of the interrelationship between returns, risk, volume and volatility for one of the emerging stock markets in Eastern Europe, namely the Russian stock market. Russia has two major stock exchanges located in Moscow, the Moscow Central Stock Exchange (MCSE) and the Moscow International Stock Exchange (MISE), and a number of regional exchanges. In 
addition, in 1994 Russia established an "over the counter" trading system in the form of the Russian Trading System (RTS), which has become one of the largest and most important stock exchanges in Russia. Since September 1, 1995 there has been a daily calculation of the RTS index, which is the official index of the Russian Trading System. The RTS index includes a listing of stocks of principally the largest and most liquid Russian companies, and is published on line at the RTS web server at www.rts.ru, where a detailed description of the methodology of the index calculation can be found. The RTS index is a dollar-denominated weighted index which, due to the methodology of calculation, is much more stable with respect to sharp fluctuations of a single stock price. The historical dynamics of the index reflects the general trends of the Russian stock market developments. From its inception in 1995 to the present, the index has experience two strong opposite movements: the rise in 1996-1997, connected with the general development of the Russian financial system and expectations for the quick revival of the market economy, and the fall in 1997-1998 caused by the Asian economic crisis in 1997, which reflected the generalized shift of investors from emerging markets, and the Russian financial crisis in 1998, caused by the default of the Russian State Treasury bonds (GKO), when the financial system of the country was practically paralyzed. After those tempestuous changes however, the market became more stable and toward the end of 1999 started steadily rising. The Russian stock market has been analyzed at length in recent years, but mainly from the viewpoint of market efficiency (Rockinger and Urga, 2000, Urga, Estrin and Lazarova, 2001, Urga and Rockinger, 2001, Hall and Urga, 2002). This paper contributes to this growing body of research on transition economies by providing some empirical evidence on the mechanisms at work in the Russian stock market that cause volatility clustering, and the interrelationships between returns, risk, volatility and volume. This analysis, in turn, allows us to answer the question of whether significant differences exist between the findings that have been documented for well-developed Western financial markets and the newly created markets of Eastern Europe, which are emerging as a result of the transition from economic planning to capitalism.

The rest of the paper is organized as follows: Section 2 outlines the MDH hypothesis and presents the structure of the theoretical models. The specification of the alternative models used in the empirical analysis is outlined in Section 3. The empirical results are contained in Section 4. During the period under investigation, the Russian economy, and consequently the Russian stock market, has been subjected to a variety of economic and political shocks, such as the stock market crash of 1997, the Russian financial crisis of 1998, and the political odyssey culminating with the resignations of Yeltsin in 1999. Consequently, we present empirical findings for both the entire period and four sub-periods corresponding to these fundamental events. Section 5 summarizes the main conclusions.

\section{The Mixture of Distributions Hypothesis}

According to the mixture of distributions hypothesis (MDH), the innovation on returns $\varepsilon_{t}$ is a linear combination of intraday returns movements, i.e.:

$$
\varepsilon_{\mathrm{t}}=\sum_{\mathrm{i}=1}^{\mathrm{nt}} \delta_{\mathrm{it}}
$$

where $\delta_{\mathrm{it}}$ is the intraday return increment in day $\mathrm{t}$ due to information flows arriving into the market and $\mathrm{n}_{\mathrm{t}}$ is the number of information arrivals within a given day. Each $\delta_{\mathrm{it}}$ is assumed to be an independent identically distributed random variable with mean zero and variance $\sigma^{2}$, i.e. $\delta_{\text {it }}$ is $N\left(0, \sigma^{2}\right)$. Since the number of intraday price increments is random, daily returns follow a mixture of normally distributed random variables with $n_{t}$ as the mixing variable. Thus, according to equation (1), the daily return $r_{t}$ is generated by a subordinate stochastic process in which $r_{t}$ is dependent on $\delta_{\mathrm{it}}$ and the mixing variable $\mathrm{n}_{\mathrm{t}}$ is the directing process. Under the assumption that the number of information arrivals $n_{t}$ follows an autoregressive process, i.e.:

$$
\mathrm{n}_{\mathrm{t}}=\varphi_{0}+\varphi_{1}(\mathrm{~L}) \mathrm{n}_{\mathrm{t}-1}+\mathrm{u}_{\mathrm{t}}
$$


where $\varphi_{1}(L)$ is a polynomial in the lag operator $L$ and $u_{t}$ an error term. The conditional variance of the daily returns can be represented as:

$$
\sigma_{r_{t} \mid n_{t}}^{2}=E\left(r_{t}^{2} \mid n_{t}\right)
$$

Substituting the autoregressive process in equation (2) into equation (3) yields:

$$
\sigma_{\mathrm{r}_{\mathrm{t}} \mid \mathrm{n}_{\mathrm{t}}}^{2}=\sigma^{2}\left(\varphi_{0}+\varphi_{1}(\mathrm{~L}) \mathrm{n}_{\mathrm{t}-1}+\mathrm{u}_{\mathrm{t}}\right)=\sigma^{2} \varphi_{0}+\varphi_{1}(\mathrm{~L}) \sigma_{\mathrm{r}_{\mathrm{t}-1} \mid \mathrm{n}_{\mathrm{t}-1}}^{2}+\sigma^{2} \mathrm{u}_{\mathrm{t}}
$$

Equation (4) illustrates the fundamental feature of the $\mathrm{MDH}$, i.e. that the autoregressive structure of the mixing variable $n_{t}$ is translated into the GARCH structure of the conditional variance of the returns. The more information flows (news) arrive into the market, the more traders will interpret the effects of such information flows differently, and the more they will have an incentive to trade as their expectations on future returns diverge. Following this argument, the GARCH behavior of the daily stock returns is generated by a serially correlated information flow process, where information arrivals can be proxied by the volume of trade (Lamoureux and Lastrapes, 1990), i.e.:

$$
\mathrm{v}_{\mathrm{t}}=\xi\left(\mathrm{n}_{\mathrm{t}}\right)
$$

which implies that the conditional variance $\mathrm{h}_{\mathrm{t}}{ }^{2}$ of the daily returns takes the form:

$$
\mathrm{h}_{\mathrm{t}}^{2}=\omega_{0}+\alpha_{1}(\mathrm{~L}) \varepsilon_{\mathrm{t}-1}^{2}+\beta_{1}(\mathrm{~L}) \mathrm{h}_{\mathrm{t}-1}^{2}+\gamma \mathrm{v}_{\mathrm{t}}
$$

where $\alpha_{1}(\mathrm{~L})$ and $\beta_{1}(\mathrm{~L})$ are polynomials in the lag operator $\mathrm{L}$, and $\mathrm{v}_{\mathrm{t}}$ is a measure of trading activity. Equation (6) models the variance of unexpected returns as a GARCH process with daily trading activity $\mathrm{v}_{\mathrm{t}}$ as a proxy for the number of information flows arrivals but does not differentiate on the type of information flows into the market. A further insight into the MDH can be obtained by assuming that qualitatively different types of information flows cause different innovations in returns. This suggests decomposing $\varepsilon_{t}$ into positive (good news) and negative (bad news) innovations in daily returns (Depken, 2001). This leads to the alternative formulation:

$$
\varepsilon_{\mathrm{t}}=\sum_{i=1}^{n+t} \delta_{\mathrm{it}}^{+}+\sum_{i=1}^{n-t} \delta_{\mathrm{it}}^{-}
$$

where $\mathrm{n}_{t}^{+}$is the number of positive information flows into the market and $\mathrm{n}_{\mathrm{t}}^{-}$is the number of negative information flows into the market on a given day, and, correspondingly, $\delta^{+}{ }_{\text {it }}$ and $\delta_{\text {it }}$ are the intraday return increments due to good news and bad news on day t. Letting

$$
\mathrm{v}_{\mathrm{t}}=\xi\left(\mathrm{n}_{\mathrm{t}}^{+}, \mathrm{n}_{\mathrm{t}}^{-}\right)=\xi_{1}\left(\mathrm{n}_{\mathrm{t}}^{+}\right)+\xi_{2}\left(\mathrm{n}_{\mathrm{t}}^{-}\right)
$$

with $\mathrm{v}_{\mathrm{t}}^{+}=\xi_{1}\left(\mathrm{n}_{\mathrm{t}}^{+}\right)$and $\mathrm{v}_{\mathrm{t}}^{-}=\xi_{2}\left(\mathrm{n}_{\mathrm{t}}^{-}\right)$representing positive and negative changes in the trading volume due respectively, to positive and negative news, yields an alternative specification of the conditional variance of the returns:

$$
\mathrm{h}_{\mathrm{t}}^{2}=\omega+\alpha_{1}(\mathrm{~L}) \varepsilon_{\mathrm{t}-1}^{2}+\beta_{1}(\mathrm{~L}) \mathrm{h}_{\mathrm{t}-1}^{2}+\gamma_{1} \mathrm{v}_{\mathrm{t}}^{+}+\gamma_{2} \mathrm{v}_{\mathrm{t}}^{-} .
$$




\section{Model Specification}

In order to analyze the GARCH structure of the RTS index return and to test the MDH, we need to specify the mean and variance equations. Researchers have used different specifications for the mean equation, with and without in-mean effects. One of the most common mean equations of returns is the ARCH-M model of Engle, Lilien and Robins (1987) and its immediate generalization, the GARCH-M model, which has been frequently used in empirical studies of stock markets (Elysiani and Mansur, 1998, Black and Fraser, 1995) to model the intertemporal relation between risk and returns. The reported findings on the relationship between risk and returns, however, are somewhat conflicting. Glosten, Jagannathan and Runckle (1993), as well as Nelson (1991), for example, find a negative relationship between risk and returns, while Campbell and Hentschel (1992) conclude that the data are consistent with a positive relation between returns and conditional variance. In addition, in order to carry out our analysis we need to choose a form for the mean equation. Researchers have suggested different specifications. Hentschel (1995) modeled returns as a white noise process. Nelson (1991), as well as Corhay and Rad (1994), instead, used an AR(1) specification, while Ding, Engle and Granger (1993) used an MA(1) specification. Following Karanasos and Kim (2000), we adopt two specifications for the mean equation: an AR(1) and an MA(1) specification with in-mean effects, resulting in two conditional mean equations of the returns:

$$
\begin{aligned}
& r_{t}=\phi_{0}+\phi_{1} r_{t-1}+\delta h_{t}^{2}+\varepsilon_{t}, \\
& r_{t}=\theta_{0}+\theta_{1} \varepsilon_{t-1}+\delta h_{t}^{2}+\varepsilon_{t},
\end{aligned}
$$

In both equations (10) and (11), the conditional variance is allowed to influence the conditional mean, resulting in a time-varying risk premium, which is parameterized as $\delta \mathrm{h}_{\mathrm{t}}^{2}$, with $\delta$ measuring the relative degree of risk aversion. The distribution of the stochastic error $\varepsilon_{\mathrm{t}}$ conditional on the realized values of the set $\Omega_{\mathrm{t}-1}=\left\{\varepsilon_{\mathrm{t}-1}, \ldots, \varepsilon_{\mathrm{t}-\mathrm{q}}\right\}$ is assumed approximately normal with mean zero and variance $\mathrm{h}_{\mathrm{t}}^{2}$, i.e., $\varepsilon_{\mathrm{t}} \mid \Omega_{\mathrm{t}-1} \sim \mathrm{N}\left(0_{1}, \mathrm{~h}^{2}\right)$. For the variance equation, we examine three alternative specifications. The first is the standard Bollerslev's GARCH(1,1) model:

$$
\mathrm{h}_{\mathrm{t}}^{2}=\omega+\alpha_{1} \varepsilon_{\mathrm{t}-1}^{2}+\beta_{1} \mathrm{~h}_{\mathrm{t}-1}^{2}
$$

where $\omega, \alpha_{1}$, and $\beta_{1}>0$, and $\alpha_{1}+\beta_{1}<1$ to ensure stationarity of the return process and positivity of the conditional variance. The persistence of the conditional variance is measured by the value of $\alpha_{1}+\beta_{1}$. The volatility process becomes more persistent as $\alpha_{1}+\beta_{1}$ approaches one. The second specification augments equation (12) by the change in trading volume as an exogenous explanatory variable:

$$
\mathrm{h}_{\mathrm{t}}^{2}=\omega+\alpha_{1} \varepsilon_{\mathrm{t}-1}^{2}+\beta_{1} \mathrm{~h}_{\mathrm{t}-1}^{2}+\gamma \mathrm{v}_{\mathrm{t}}
$$

The variance specification in equation (13) incorporates a direct test of the MDH. The test can be performed either by examining the statistical significance of $\gamma$, or conducting a likelihood ratio test of (12) against (13). Finally, the third specification decomposes $\mathrm{v}_{\mathrm{t}}$ into its positive and negative components, respectively:

$$
h_{t}^{2}=\omega_{0}+\alpha_{1} \varepsilon_{t-1}^{2}+\beta_{1} h_{t-1}^{2}+\gamma_{1} D_{1, t} v_{t}+\gamma_{2} D_{2, t} v_{t}
$$

where $\mathrm{D}_{1, \mathrm{t}}$ and $\mathrm{D}_{2, \mathrm{t}}$ are dummy variables designed to capture, respectively, the positive and negative components of $v_{t}\left(D_{1, t}=1\right.$ when $v_{t}>0$ and 0 otherwise and, similarly, $D_{2, t}=1$ when $v_{t}<0$ and 0 otherwise $)$. This parametric specification tests the hypothesis that positive and negative changes in trading volume affect asymmetrically the conditional variance of the returns. A test of symmetry of the effects of positive and negative volume can be conducted using a Wald test of equality of $\gamma_{1}$ and $\gamma_{2}$.

In summary, the two specifications of the mean equation combined with the three specifications of the variance equation yield the following six models: 1) $\operatorname{AR}(1)-\operatorname{GARCH}(1,1)$ in mean (equations (10) and (12)); 
2) MA(1)-GARCH(1,1) in mean (equations (11) and (12)); 3) $\operatorname{AR}(1)-\operatorname{GARCH}(1,1)$ in mean with volume (equations (10) and (13)); 4) MA(1)-GARCH(1,1) in mean with volume (equations (11) and (13)); 5)AR(1)-GARCH(1,1) in mean with decomposed volume (equations (10) and (14)); 6) MA(1)-GARCH(1,1) in mean with decomposed volume (equations (11) and (14)). The variance specification in equation (12) is a special case of equation (13), with the coefficient on the change in trading volume $\gamma$ constrained to zero. In turn, the variance specification in equation in (13) is a special case of equation (14), which relaxes the restriction $\gamma_{1}=\gamma_{2}$. Thus, the $\operatorname{AR}(1)-\operatorname{GARCH}(1,1)-\mathrm{M}$ and MA(1)-GARCH(1,1)-M represent the (restricted) benchmark models, against which the remaining (unrestricted) models can be used to test both the validity of the MDH and the hypothesis of asymmetrical effects.

\section{Empirical Results}

For the purpose of empirical analysis, the daily return on the RTS index is defined as $r_{t}=100 * \ln \left(R_{T S} / R_{t} S_{t-1}\right)$, where RST denotes the value of the Russian Trading System index at the close of day $t$. Similarly, the daily change in trading volume is defined as $v_{t}=100 * \ln \left(\operatorname{vol}_{t} / \operatorname{vol}_{t-1}\right)$ where $v l_{t}$ indicates the total trading volume (denominated in billions of dollars) at the close of day t. Summary statistics for the RTS returns are reported in Table 1 for both the full sample period (September 1, 1995 to December 31, 2002) and four sub-periods, since the Chow breaking point test on the $\mathrm{AR}(1)$ and $\mathrm{MA}(1)$ specifications of the returns equation rejected the hypothesis of parameter stability over the full sample. For the AR(1) specification the LR test produced a $\chi^{2}$ value of 25.78, while the corresponding value for the MA(1) specification was 34.0. These values are well above the critical value of the $\chi^{2}$ distribution with 6 degrees of freedom. The first sub-period spans the interval from September 1,1995 until the Russian stock market crash on October 28, 1997. The next sub-period starts on October 29, 1997 and ends on August 19, 1998, one week before the Russian financial crisis of August 27, 1998. The third sub-period includes the Russian financial crisis and its aftermath, from the various economic reform "packages" to the dramatic erosion of political power of the Yeltsin presidency, and runs from August 20, 1998 until December 30, 1999. Finally, the last period starts on December 31, 1999, the day the Putin presidency began, following the Yeltsin resignation, and ends on December 31, 2002.

Inspection of Table 1 reveals that the RTS returns behave in a complex manner. The mean of the RTS returns ranges from -0.8085 percent in the second sub-period (after the stock market crash) to +0.2808 percent in the first sub-period (before the crash), even though over the entire period is not significantly different from zero. Similarly, the standard deviation of the RTS returns varies from 4.4509 per cent in the second sub-period to 2.5734 per cent in the forth sub-period (the Putin presidency). As Table 1 clearly indicates, the distribution of the RTS returns is skewed and leptokurtic. Skewness, however, is not significantly different from zero in the second and third sub-periods, based on the standard error computed as $(6 / \mathrm{N})^{1 / 2}$ where $\mathrm{N}$ is the number of observations. In the first and third sub-periods, instead, the coefficient is significantly different from zero and negative. This finding is similar to what has been found in well-established markets, such the U.S. and the Japanese stock market, where returns display negative skewness (Ding and Granger, 1996). Excess kurtosis, on the other hand, is significantly different from zero in the full sample as well as in the four sub-periods, based on the standard error calculated as $(24 / \mathrm{N})^{1 / 2}$, suggesting that the distributions of the RTS returns have thicker tails than the normal distribution irrespective of the chosen period. The Jarque-Bera test upholds the non-normality of the returns in both the full sample and each of the four sub-periods. This comes as no surprise, as it is a common finding in empirical work that the distribution of most financial returns is non-normal. Although not reported, the Lilliefors (D), Cramer-von Mises (W2), Watson (U2), and Anderson-Darling (A2) tests further confirm the (unconditional) non-normality of the RTS returns. The LjungBox Q-statistics indicate that the RTS returns are highly serially correlated over the full sample period. However, when the sub-periods are individually considered, a different picture emerges. In particular, the RTS returns show a high degree of serial correlation only in the first and third sub-periods, thus confirming Urga and Rockinger's (2001) findings of parametric instability of the autoregressive component of the returns. The highest positive autocorrelation is observed in the first and third sub-periods, with a first-order autocorrelation coefficient of 0.213 and 0.228 , respectively. This indicates that about 5 per cent of the RTS daily returns variation is predictable using only the preceding day's returns. This is contrary to most theoretical models of market efficiency, which generally 
require returns to be serially uncorrelated, and may be the observed effect of non-synchronous trading, time-varying risk premia, or profit taking (Boudoukh et al., 1994). The second-order autocorrelation coefficient is not statistically significant, based on Bartlett's standard error, in any of the sub-periods and in the full sample. Although not reported, there are no signs of any consistent higher-order return autocorrelation. The Ljung-Box Q-statistics for the squared returns indicate that higher order moment temporal dependencies are present, even at high lags, which is a sign of ARCH effects (Bollerslev, Chou and Kroner, 1992). The existence of serial correlation in $v_{t}$ is essential for any test of the MDH, since the MDH implies that serial correlation in $\mathrm{v}_{\mathrm{t}}$ causes conditional heteroskedasticity in $\mathrm{r}_{\mathrm{t}}$, and the Ljung-Box Q-statistics in Table 2 indicate that $\mathrm{v}_{\mathrm{t}}$ is highly correlated both in the full sample and the four sub-samples. In addition, the Ljung-Box Q-statistics for $\mathrm{v}_{t}$ squared suggest the presence of ARCH effects also in $\mathrm{v}_{\mathrm{t}}$ with the exception of the second sub-period. Finally, Tables 1 and 2 present the results of the augmented DickeyFuller (ADF) and Phillips-Perron (PP) tests for a unit root in $r_{t}$ and $v_{t}$. The augmented Dickey-Fuller regressions contain a constant term and their augmentations are determined according to the Schwarz-Bayes information criterion. Testing for the existence of unit root in $\mathrm{v}_{\mathrm{t}}$ is particularly important, since the tests of the effects of $\mathrm{v}_{\mathrm{t}}$ on $\mathrm{h}^{2}$ are invalid in case $v_{t}$ contains a unit root. As these tables clearly indicate, both the ADF and PP tests reject (at conventional levels) the unit root hypothesis, thus providing evidence in favor of stationarity for both $\mathrm{r}_{\mathrm{t}}$ and $\mathrm{v}_{\mathrm{t}}$.

The results of the estimation of the benchmark models are presented in Tables 3 and 4. Parameter estimates are quasi-maximum likelihood estimates obtained by means of the Marquardt algorithm. The heteroskedasticity consistent standard errors in parenthesis are computed using the methods described by Bollerslev and Woolridge (1992). Clearly, the conditional mean equation estimated over the entire period shows signs of misspecification regardless of its parametric specification. The Ljung-Box Q statistics indicate that both the AR(1) and MA(1) models have significant autocorrelation in the standardized residuals. There are probably several sources that account for this misspecification, one of which is likely to be related to the parametric instability of the model, as shown by Urga and Rockinger (2001). This conjecture is confirmed by the parameter estimates in each of the four sub-periods. As with the autocorrelations, the AR parameter $\phi_{1}$ is statistically significant in the first and third subperiods, but is not significant in the second and fourth sub-periods. Similarly, the MA parameter $\theta_{1}$ is significant only in the first and third sub-periods, and its value is very close to the AR parameter. Thus, there is evidence of significant predictability in the returns in the first and third sub-periods, but there is no evidence of predictability in the second and fourth sub-periods.

In each of the sub-periods, the coefficients of $\alpha_{1}$ and $\beta_{1}$ are significant at the 0.01 level, and the persistence of the conditional variance, as measured by the sum of $\alpha_{1}$ and $\beta_{1}$, is very high, ranging from 0.86 in the third subperiod to 0.99 in the first one, implying that a shock to the conditional variance persists almost indefinitely. Alternatively, the "half-life" of a shock, that is, the time that the conditional variance takes to revert halfway to its unconditional value, ranges approximately from 5 days in the third sub-period to 70 days in the first sub-period. In addition, in each of the four sub-periods, irrespective of the mean equation specification, the Ljung -Box Q-statistics indicate that the standardized residuals and squared standardized residuals are uncorrelated. The Jarque-Bera normality test statistics of the standardized residuals for both models are far beyond the critical value of a normal distribution, as assumed by both models. This is not surprising since there are other factors affecting the volatility. It is also not a substantial problem since, conditionally, normality permits excess kurtosis in the data. A problem, however, is present with the parameter estimate of the time-varying risk premium. According to portfolio theory, the parameter $\delta$ should be positive and statistically significant. Yet, all estimated models indicate a statistically insignificant (at conventional levels) relationship between risk and return, which is another possible sign of misspecification. Alternatively, another plausible explanation for the insignificance of the estimates of $\delta$ is the high level of noisiness of the realized returns. If this is the case, the inclusion of a variable, such as $\mathrm{v}_{\mathrm{t}}$, in addition to the conditional volatility, which is correlated with $r_{t}$, may lead to an improvement in the efficiency of estimation of the parameter $\delta$.

Tables 5 and 6 report the relevant parameter estimates and related statistics for the models AR(1)GARCH(1,1)-M and MA(1)-GARCH(1,1)-M with the change in volume as the additional regressor in the variance equation. As the tables clearly indicate, this specification is successful in explaining the persistence in conditional 
variance. The parameter $\gamma$ is positive and significant at the 0.01 level in both the AR(1) and MA(1) specification of the conditional mean, and for both the full sample period and the four sub-periods. Two important differences, however, are apparent between the results of the full sample and those of the four sub-periods. The first is that the results for the four sub-periods show no evidence of serial correlation in the residuals. The second is that the persistence in conditional volatility remains very high in the full sample. A completely different picture, instead, emerges in the four sub-periods. In the case of the AR(1) specification, the addition of $v_{t}$ has the effect of sharply decreasing the estimates of $\alpha_{1}$ and $\beta_{1}$ with the result that the persistence in conditional volatility shows a declining pattern, going from 0.79 in the first sub-period to 0.61 in the last one. This has the effect of reducing the "half-life" of a shock to approximately 1 to 3 days. Similar results are obtained using the MA(1) specification of the mean equation. These findings provide clear evidence in favor of the MDH. A similar conclusion is obtained from the Akaike information criterion (AIC) and the Schwarz-Bayes information criterion (SIC), as well as from the loglikelihood function, all of which indicate that the $\operatorname{GARCH}(1,1)$ in mean with volume is superior to the $\operatorname{GARCH}(1,1)$ in mean only. The persistence effects, however, do not vanish. One plausible explanation for this is that the intraday increments are not independent identically distributed but serially correlated, as one would probably expect as a result of some degree of sluggishness inherent to any newly established markets. This implies that measures of lagged changes in trading volume, in addition to the current change, may have an impact on volatility. This hypothesis, however, will not be explored in this paper.

Interestingly, regardless of the mean equation specification, the parameter estimates for $\gamma$ increase significantly after the stock market crash, approximately from 0.02 to 0.10 , as does risk aversion, because the parameter estimate for $\delta$ also significantly increases, while the predictability of the returns significantly diminishes. This indicates a greater investors' alertness to risk and information flows to the market as well as an increased market efficiency after the stock market crash. It thus appears that as a result of stock market catastrophe of October 28,1997 , investors have learned to better process the flows of information arriving to the market and better assess its risk content. Also, the relationship between returns and time-varying risk premium turns out to be significant. Risk, as predicted by portfolio theory, has a positive impact on returns. This clearly arises from the significance of the information content of trading volume, which affects returns through volatility: increases in volatility increase risk which in turn increases returns. It is thus clear that trading volume has both a direct effect on volatility and an indirect effect on returns, confirming the hypothesis that information flows arriving in the market, and proxied by the trading volume, affect both risk and returns. Consequently, it appears that it is new information arrival to the market, rather than uncertainty, which determines risk.

The declining pattern of conditional volatility becomes more pronounced when the assumption $\gamma_{1}=\gamma_{2}$ is relaxed. The relevant parameter estimates and related statistics are presented in Tables 7 and 8 . Both $\gamma_{1}$ and $\gamma_{2}$ are positive and significant at the 0.01 level. A Wald test for symmetry of the effects of positive and negative changes in volume rejects the variance specification proposed by Lamoureux and Lastrapes (1990) in the last two sub-periods, where the decomposition of volume captures more of the persistence of variability apparent in the data than does volume alone. In the two sub-periods where the Wald test rejects the symmetry hypothesis, the results indicate that, contrary to the findings for developed, highly liquid stock markets in Western industrial countries, positive changes in volume have a greater impact on volatility than negative changes. In addition, the decomposition of the trading volume alters the size but not the statistical significance of $\delta$, and does not affect the predictability pattern of the returns, which remains as significant in the first and third sub-periods as it was when volume was not decomposed.

\section{Conclusions}

This research has tested the validity of the MDH for the Russian stock market using a GARCH(1,1)-M representation of the RTS returns. The findings lend support to the MDH, since volume is significantly positive in the variance equation, and the sum of the GARCH coefficients decline substantially. Volume, taken as a proxy for the information flows arrival to the market, is found to affect directly the relationship between information flows and volatility, and indirectly the relationship between volatility and returns. The incorporation of volume in the 
variance equation gives rise to a positive and significant the risk-return relationship, as theorized by portfolio theory, and helps to explain the presence of GARCH effects in the RTS returns, as theorized by the mixture of distribution hypothesis. In addition, the decomposition of the change in trading volume into its positive and negative components further contributes to the impounding of the GARCH effects, as predicted by the modified version of the mixture of distribution hypothesis, without altering the risk-return relationship. Thus, the results of the analysis highlight that even in an emerging and turbulent market like the Russian stock market, risk and return are jointly integrated to the flow of information arrival.

\section{References}

1. Black, A., and P. Fraser (1995), "U.K. Stock Returns: Predictability and Business Conditions", Manchester School of Economics and Social Studies, 63, Supplement, 85-102.

2. Bohl, M., and H. Henke (2002), Trading Volume and Stock Market Volatility: The Polish Case, Mimeo, European University Viadrina Frankfurt/Oder 2002.

3. Bollerslev, T. (1986), "Generalized Autoregressive Conditional Heteroskedasticity", Journal of Econometrics, 31, 307-327.

4. Bollerslev, T., R. Chou, and K. Kroner (1992), "ARCH Modelling in Finance: A Review of the Theory and Empirical Evidence", Journal of Econometrics, 52, 5-59.

5. Bollerslev, T., and J. M. Woolridge (1992), "Quasi-Maximum Likelihood Estimation and Inference in Dynamic Models with Time-Varying Covariances", Econometric Reviews, 11, 134-172.

6. Boudoukh, J., S. J. Grossman, and J. Wang (1993), "A Tale of Three Schools: Insights on Autocorrelations of Short-Horizon Stock Returns", Review of Financial Studies, 7, 539-573.

7. Brailsford, T. (1996), "The Empirical Relationship Between Trading Volume, Returns and Volatility", Accounting and Finance, 35, 89-111.

8. Campbell, J.Y., and L. Hentschel (1992), "No News is Good News: An Asymmetric Model of Changing Volatility in Stock Returns", Journal of Financial Economics, 31, 281-318.

9. Clark, P.K. (1973), "A Subordinated Stochastic Process Model with Finite Variance for Speculative Prices", Econometrica, 41, 135-155.

10. Corhay, A., and A. Rad (1994), "Statistical Properties of Daily Returns: Evidence from the European Stock Market", Journal of Business and Accounting, 21, 271-282.

11. Depken, C.A. (2001), "Good News, Bad News and GARCH Effects in Stock Return Data", Journal of Applied Economics, 4, 313-327.

12. Ding, Z., and C.W.J. Granger (1996), "Modeling Volatility Persistence of Speculative Returns: A New Approach", Journal of Econometrics, 73, 185-215.

13. Ding, Z., C.W.J. Granger, and R. Engle (1993), "A Long Memory Property of Stock Market Returns and a New Model", Journal of Empirical Finance, 1, 83-106.

14. Elyasiani, E., and I. Mansur (1998), "Sensitivity of the Bank Stock Returns Distribution to Changes in the Level and Volatility of Interest Rate: A GARCH-M Model”, Journal of Banking and Finance, 22, 535-563.

15. Engle, R. F. (1982), "Autoregressive Conditional Heteroscedasticity with Estimates of the Variance of U.K. Inflation”, Econometrica, 50, 987-1008.

16. Engle, R., Lilien, D., and R. Robins (1987), "Estimating Time Varying Risk Premia in the Term Structure: The ARCH-M Model”, Econometrica, 55, 391-407.

17. Epps, W. and M. Epps (1976), "The Stochastic Dependence of Security Price Changes and Transaction Volumes: Implications for the Mixture of Distributions Hypothesis", Econometrica, 44, 305-321.

18. Gallo, G.M., and B. Pacini (2000), "The Effects of Trading Activity on Market Volatility", European Journal of Finance, 6, 163-175.

19. Glosten, L., Jagannathan, R., and D. Runkle, "On the Relation Between the Expected Value and the Volatility of the Nominal Excess Return on Stocks", Journal of Finance, 5, 1779-1801. 
20. Hall, S., and G. Urga (2002), Testing for Ongoing Efficiency in the Russian Stock Market 1970-1999, Mimeo, City University Business School, May 2002.

21. Hentschel, L. (1995), "All in the Family-Nesting Symmetric and Asymmetric GARCH Models", Journal of Finance, 39, 71-104.

22. Karansasos, M., and Kim, J.(2000), Alternative GARCH in Mean Models: An Application to the Korean Stock Market, Discussion Paper in Economics, University of York, 2000.

23. Kim, D., and S. Kon (1994), "Alternative Models for the Conditional Heteroskedasticity of Stock Returns", Journal of Business, 67, 563-588.

24. Lamoureux, C., and W. Lastrapes (1990), "Heteroskedasticity in Stock Returns Data: Volume versus GARCH Effects", Journal of Finance, 45, 221-229.

25. Nelson, D.B. (1991), "Conditional Heteroskedasticity in Asset Returns: A New Approach", Econometrica, 59, 347-370.

26. Ormran, M., and E. T. McKenzie (2000), "Heteroskedasticity in Stock Returns Data Revisited: Volume versus GARCH Effects", Applied Financial Economics, 10, 553-560.

27. Rockinger, M., and G. Urga (2000), "The Evolution of Stock Markets in Transition Economies", Journal of Comparative Economics, 28, 456-472.

28. Tauchen, G., and M. Pitts (1983), "The Price Variability-Volume Relationship in Speculative Markets", Econometrica, 51, 485-505.

29. Urga, G., S. Estrin,, and S. Lazarova (2001), "Testing for Ongoing Convergence in Transition Economies, 1970-1999”, Journal of Comparative Economics, 29, 677-691.

30. Urga, G., and M. Rockinger (2001), "A Time Varying Parameter Model to Test for Predictability and Integration in Stock Markets in Transition Economies", Journal of Business and Economic Statistics, 19, 73-84.

Table 1: Unconditional Distributional Statistics for $\mathbf{r}_{\mathbf{t}}$

\begin{tabular}{|c|c|c|c|c|c|}
\hline & $\begin{array}{l}9 / 1 / 95 \text { to } \\
12 / 31 / 02 \\
\end{array}$ & $\begin{array}{l}\text { 9/1/95 to } \\
10 / 28 / 97 \\
\end{array}$ & $\begin{array}{l}10 / 29 / 97 \text { to } \\
8 / 19 / 98 \\
\end{array}$ & $\begin{array}{l}8 / 20 / 98 \text { to } \\
12 / 30 / 99 \\
\end{array}$ & $\begin{array}{l}12 / 31 / 99 \text { to } \\
12 / 31 / 02\end{array}$ \\
\hline \multicolumn{6}{|l|}{ Normality tests } \\
\hline Mean & 0.0697 & 0.2808 & -0.8085 & 0.1479 & 0.1161 \\
\hline Std deviation & 3.2386 & 3.0569 & 4.4509 & 3.8599 & 2.5734 \\
\hline Skewness & -0.3114 & -0.2730 & 0.0852 & -0.5399 & -0.0482 \\
\hline Kurtosis & 7.4180 & 10.2112 & 4.3073 & 6.3385 & 5.8752 \\
\hline Jarque-Bera & 1522.0090 & 1174.5680 & 14.4837 & 176.4604 & 259.3128 \\
\hline $\mathrm{p}$ value & 0.0000 & 0.0000 & 0.0007 & 0.0000 & 0.0000 \\
\hline \multicolumn{6}{|c|}{ Autocorrelation tests } \\
\hline $\begin{array}{l}\mathrm{Q}_{12}\left[\mathrm{r}_{\mathrm{t}}\right] \\
\mathrm{p} \text { value }\end{array}$ & $\begin{array}{l}73.7450 \\
0.0000\end{array}$ & $\begin{array}{l}32.6340 \\
0.0010\end{array}$ & $\begin{array}{l}17.4920 \\
0.1320\end{array}$ & $\begin{array}{l}22.8340 \\
0.0290\end{array}$ & $\begin{array}{l}11.3110 \\
0.5020\end{array}$ \\
\hline $\begin{array}{l}\mathrm{Q}_{24}\left[\mathrm{r}_{\mathrm{t}}\right] \\
\mathrm{p} \text { value }\end{array}$ & $\begin{array}{l}98.1900 \\
0.0000\end{array}$ & $\begin{array}{l}42.9140 \\
0.0100\end{array}$ & $\begin{array}{l}32.8560 \\
0.1070\end{array}$ & $\begin{array}{l}33.5520 \\
0.0930\end{array}$ & $\begin{array}{l}30.2720 \\
0.1760\end{array}$ \\
\hline $\begin{array}{l}\mathrm{Q}_{36}\left[\mathrm{r}_{\mathrm{t}}\right] \\
\mathrm{p} \text { value }\end{array}$ & $\begin{array}{l}114.0000 \\
0.0000\end{array}$ & $\begin{array}{l}58.1590 \\
0.0110\end{array}$ & $\begin{array}{l}47.0530 \\
0.1030\end{array}$ & $\begin{array}{l}48.3800 \\
0.0810\end{array}$ & $\begin{array}{l}40.9950 \\
0.2610\end{array}$ \\
\hline $\begin{array}{l}\mathrm{Q}_{12}\left[\mathrm{r}_{\mathrm{t}}\right]^{2} \\
\mathrm{p} \text { value }\end{array}$ & $\begin{array}{l}429.2100 \\
0.0000\end{array}$ & $\begin{array}{l}126.2200 \\
0.0000\end{array}$ & $\begin{array}{l}23.1780 \\
0.0260\end{array}$ & $\begin{array}{l}34.7080 \\
0.0010\end{array}$ & $\begin{array}{l}105.5100 \\
0.0000\end{array}$ \\
\hline $\begin{array}{c}\mathrm{Q}_{24}\left[\mathrm{r}_{\mathrm{t}}\right]^{2} \\
\mathrm{p} \text { value }\end{array}$ & $\begin{array}{l}559.8500 \\
0.0000\end{array}$ & $\begin{array}{l}158.5800 \\
0.0000\end{array}$ & $\begin{array}{l}37.4170 \\
0.0400\end{array}$ & $\begin{array}{l}46.7400 \\
0.0040\end{array}$ & $\begin{array}{l}130.6100 \\
0.0000\end{array}$ \\
\hline $\begin{array}{c}\mathrm{Q}_{36}\left[\mathrm{r}_{\mathrm{t}}\right]^{2} \\
\mathrm{p} \text { value } \\
\end{array}$ & $\begin{array}{l}690.0300 \\
0.0000 \\
\end{array}$ & $\begin{array}{l}168.6700 \\
0.0000 \\
\end{array}$ & $\begin{array}{l}46.7020 \\
0.1090 \\
\end{array}$ & $\begin{array}{l}62.4130 \\
0.0040 \\
\end{array}$ & $\begin{array}{l}146.6300 \\
0.0000\end{array}$ \\
\hline \multicolumn{6}{|l|}{ Unit root tests } \\
\hline $\mathrm{ADF}$ & -36.2733 & -16.5708 & -12.5535 & -14.7475 & -26.4428 \\
\hline Phillips-Perron & -36.4118 & -17.7801 & -12.5886 & -14.7142 & -26.4408 \\
\hline
\end{tabular}


Table 2: Unconditional Distributional Statistics for $v_{t}$

\begin{tabular}{|c|c|c|c|c|c|}
\hline & $\begin{array}{l}9 / 1 / 95 \text { to } \\
12 / 31 / 02 \\
\end{array}$ & $\begin{array}{l}9 / 1 / 95 \text { to } \\
10 / 28 / 97 \\
\end{array}$ & $\begin{array}{l}10 / 29 / 97 \text { to } \\
8 / 19 / 98\end{array}$ & $\begin{array}{l}8 / 20 / 98 \text { to } \\
12 / 30 / 99\end{array}$ & $\begin{array}{l}12 / 31 / 99 \text { to } \\
12 / 31 / 02\end{array}$ \\
\hline \multicolumn{6}{|l|}{ Normality tests } \\
\hline Mean & -0.0227 & 0.7421 & -1.4545 & -0.1124 & -0.1491 \\
\hline Std deviation & 54.5148 & 60.5087 & 45.2028 & 55.7187 & 51.7136 \\
\hline Skewness & 0.1899 & 0.3574 & 0.2228 & 0.1132 & 0.0129 \\
\hline Kurtosis & 5.0102 & 6.7182 & 3.6083 & 3.5401 & 3.3522 \\
\hline $\begin{array}{l}\text { Jarque-Bera } \\
\text { p value }\end{array}$ & $\begin{array}{l}320.0044 \\
0.0000\end{array}$ & $\begin{array}{l}321.9679 \\
0.0000\end{array}$ & $\begin{array}{l}4.7381 \\
0.0936\end{array}$ & $\begin{array}{l}4.9169 \\
0.0856\end{array}$ & $\begin{array}{l}3.9071 \\
0.1418\end{array}$ \\
\hline \multicolumn{6}{|c|}{ Autocorrelation tests } \\
\hline $\begin{array}{l}\mathrm{Q}_{12}\left[\mathrm{v}_{\mathrm{t}}\right] \\
\mathrm{p} \text { value }\end{array}$ & $\begin{array}{l}203.7700 \\
0.0000\end{array}$ & $\begin{array}{l}53.0060 \\
0.0000\end{array}$ & $\begin{array}{l}22.9810 \\
0.0280\end{array}$ & $\begin{array}{l}41.3410 \\
0.0000\end{array}$ & $\begin{array}{l}122.5900 \\
0.0000\end{array}$ \\
\hline $\begin{array}{l}\mathrm{Q}_{24}\left[\mathrm{v}_{\mathrm{t}}\right] \\
\mathrm{p} \text { value }\end{array}$ & $\begin{array}{l}227.7600 \\
0.0000\end{array}$ & $\begin{array}{l}79.0750 \\
0.0000\end{array}$ & $\begin{array}{l}50.7370 \\
0.0010\end{array}$ & $\begin{array}{l}53.5690 \\
0.0000\end{array}$ & $\begin{array}{l}154.7300 \\
0.0000\end{array}$ \\
\hline $\begin{array}{c}\mathrm{Q}_{36}\left[\mathrm{v}_{\mathrm{t}}\right] \\
\mathrm{p} \text { value }\end{array}$ & $\begin{array}{l}241.7300 \\
0.0000\end{array}$ & $\begin{array}{l}88.4040 \\
0.0000\end{array}$ & $\begin{array}{l}62.9350 \\
0.0040\end{array}$ & $\begin{array}{l}57.1340 \\
0.0140\end{array}$ & $\begin{array}{l}172.1900 \\
0.0000\end{array}$ \\
\hline $\begin{array}{c}\mathrm{Q}_{12}\left[\mathrm{v}_{\mathrm{t}}\right]^{2} \\
\mathrm{p} \text { value }\end{array}$ & $\begin{array}{l}135.8000 \\
0.0000\end{array}$ & $\begin{array}{l}53.0070 \\
0.0000\end{array}$ & $\begin{array}{l}9.9977 \\
0.6160\end{array}$ & $\begin{array}{l}17.5890 \\
0.1290\end{array}$ & $\begin{array}{l}35.8450 \\
0.0000\end{array}$ \\
\hline $\begin{array}{c}\mathrm{Q}_{24}\left[\mathrm{v}_{\mathrm{t}}\right]^{2} \\
\mathrm{p} \text { value }\end{array}$ & $\begin{array}{l}178.9800 \\
0.0000\end{array}$ & $\begin{array}{l}64.1900 \\
0.0000\end{array}$ & $\begin{array}{l}24.1310 \\
0.4540\end{array}$ & $\begin{array}{l}37.6290 \\
0.0380\end{array}$ & $\begin{array}{l}67.2970 \\
0.0000\end{array}$ \\
\hline $\begin{array}{c}\mathrm{Q}_{36}\left[\mathrm{v}_{\mathrm{t}}\right]^{2} \\
\mathrm{p} \text { value }\end{array}$ & $\begin{array}{l}223.3900 \\
0.0000\end{array}$ & $\begin{array}{l}76.9510 \\
0.0000\end{array}$ & $\begin{array}{l}29.3110 \\
0.7770\end{array}$ & $\begin{array}{l}62.4580 \\
0.0040\end{array}$ & $\begin{array}{l}94.2390 \\
0.0000\end{array}$ \\
\hline \multicolumn{6}{|l|}{ Unit root tests } \\
\hline $\mathrm{ADF}$ & -22.0314 & -13.3691 & -14.0280 & -13.3797 & -15.1791 \\
\hline Phillips-Perron & -143.8561 & -77.5546 & -25.8575 & -34.5834 & -73.8947 \\
\hline
\end{tabular}


Table 3: $\operatorname{AR}(1)-G A R C H(1,1)$ in mean only

\begin{tabular}{|c|c|c|c|c|c|}
\hline & $\begin{array}{l}9 / 1 / 95 \text { to } \\
12 / 31 / 02 \\
\end{array}$ & $\begin{array}{l}9 / 1 / 95 \text { to } \\
10 / 28 / 97 \\
\end{array}$ & $\begin{array}{l}10 / 29 / 97 \text { to } \\
8 / 19 / 98\end{array}$ & $\begin{array}{l}8 / 20 / 98 \text { to } \\
12 / 30 / 99 \\
\end{array}$ & $\begin{array}{l}12 / 31 / 99 \text { to } \\
12 / 31 / 02\end{array}$ \\
\hline \multicolumn{6}{|l|}{ Mean equation } \\
\hline$\phi_{0}$ & $\begin{array}{l}0.1043 \\
(0.0742)\end{array}$ & $\begin{array}{l}0.1638 \\
(0.1230)\end{array}$ & $\begin{array}{l}-0.4317 \\
(0.3767)\end{array}$ & $\begin{array}{l}-0.0469 \\
(0.2970)\end{array}$ & $\begin{array}{l}0.0410 \\
(0.1372)\end{array}$ \\
\hline$\phi_{1}$ & $\begin{array}{l}0.1646 \\
(0.0267)\end{array}$ & $\begin{array}{l}0.2596 \\
(0.0569)\end{array}$ & $\begin{array}{l}0.0884 \\
(0.0750)\end{array}$ & $\begin{array}{l}0.2202 \\
(0.0591)\end{array}$ & $\begin{array}{l}0.0667 \\
(0.0385)\end{array}$ \\
\hline$\delta$ & $\begin{array}{l}0.0021 \\
(0.0088)\end{array}$ & $\begin{array}{l}-0.0037 \\
(0.0216)\end{array}$ & $\begin{array}{l}0.0069 \\
(0.0209)\end{array}$ & $\begin{array}{l}0.0125 \\
(0.0227)\end{array}$ & $\begin{array}{l}0.0229 \\
(0.0252)\end{array}$ \\
\hline \multicolumn{6}{|c|}{ Variance equation } \\
\hline$\omega$ & $\begin{array}{l}0.4508 \\
(0.1287)\end{array}$ & $\begin{array}{l}0.5213 \\
(0.3389)\end{array}$ & $\begin{array}{l}0.9450 \\
(0.5972)\end{array}$ & $\begin{array}{l}2.2292 \\
(1.0379)\end{array}$ & $\begin{array}{l}0.1995 \\
(0.0923)\end{array}$ \\
\hline$\alpha_{1}$ & $\begin{array}{l}0.2259 \\
(0.0411)\end{array}$ & $\begin{array}{l}0.3145 \\
(0.1124)\end{array}$ & $\begin{array}{l}0.2622 \\
(0.1131)\end{array}$ & $\begin{array}{l}0.2867 \\
(0.0736)\end{array}$ & $\begin{array}{l}0.1109 \\
(0.0309)\end{array}$ \\
\hline$\beta_{1}$ & $\begin{array}{l}0.7479 \\
(0.0404)\end{array}$ & $\begin{array}{l}0.6721 \\
(0.1210)\end{array}$ & $\begin{array}{l}0.7307 \\
(0.0924)\end{array}$ & $\begin{array}{l}0.5795 \\
(0.1068)\end{array}$ & $\begin{array}{l}0.8563 \\
(0.0351)\end{array}$ \\
\hline$\alpha_{1}+\beta_{1}$ & $\begin{array}{l}0.9737 \\
(0.0197) \\
\end{array}$ & $\begin{array}{l}0.9866 \\
(0.0589) \\
\end{array}$ & $\begin{array}{l}0.9929 \\
(0.0478)\end{array}$ & $\begin{array}{l}0.8662 \\
(0.0934) \\
\end{array}$ & $\begin{array}{l}0.9673 \\
(0.0172) \\
\end{array}$ \\
\hline \multicolumn{6}{|l|}{ Statistics } \\
\hline Log-likelihood & -4475.6090 & -1248.6800 & -567.1548 & -922.1733 & -1718.1820 \\
\hline AIC & 4.8899 & 4.6728 & 5.7315 & 5.3964 & 4.5856 \\
\hline SIC & 4.9080 & 4.7207 & 5.8305 & 5.4633 & 4.6225 \\
\hline $\begin{array}{c}\mathrm{Q}_{12}\left[\varepsilon_{\mathrm{t}} / \mathrm{h}_{\mathrm{t}}\right] \\
\mathrm{p} \text { value }\end{array}$ & $\begin{array}{l}29.1420 \\
0.0040\end{array}$ & $\begin{array}{l}18.9920 \\
0.0890\end{array}$ & $\begin{array}{l}13.6570 \\
0.3230\end{array}$ & $\begin{array}{l}6.8074 \\
0.8700\end{array}$ & $\begin{array}{l}10.6410 \\
0.5600\end{array}$ \\
\hline $\begin{array}{c}\mathrm{Q}_{24}\left[\varepsilon_{\mathrm{t}} / \mathrm{h}_{\mathrm{t}}\right] \\
\mathrm{p} \text { value }\end{array}$ & $\begin{array}{l}38.9250 \\
0.0280\end{array}$ & $\begin{array}{l}24.1310 \\
0.4540\end{array}$ & $\begin{array}{l}26.7620 \\
0.3160\end{array}$ & $\begin{array}{l}20.9390 \\
0.6420\end{array}$ & $\begin{array}{l}23.1320 \\
0.5120\end{array}$ \\
\hline $\begin{array}{c}\mathrm{Q}_{36}\left[\varepsilon_{\mathrm{t}} / \mathrm{h}_{\mathrm{t}}\right] \\
\mathrm{p} \text { value }\end{array}$ & $\begin{array}{l}50.1150 \\
0.0590\end{array}$ & $\begin{array}{l}37.2060 \\
0.4130\end{array}$ & $\begin{array}{l}44.6970 \\
0.1520\end{array}$ & $\begin{array}{l}32.5570 \\
0.6330\end{array}$ & $\begin{array}{l}32.8920 \\
0.6170\end{array}$ \\
\hline $\begin{array}{c}\mathrm{Q}_{12}\left[\varepsilon_{\mathrm{t}} / \mathrm{h}_{\mathrm{t}}\right]^{2} \\
\mathrm{p} \text { value }\end{array}$ & $\begin{array}{l}11.3430 \\
0.5000\end{array}$ & $\begin{array}{l}5.9786 \\
0.9170\end{array}$ & $\begin{array}{l}8.2954 \\
0.7620\end{array}$ & $\begin{array}{l}7.1220 \\
0.8490\end{array}$ & $\begin{array}{l}2.5821 \\
0.9980\end{array}$ \\
\hline $\begin{array}{c}\mathrm{Q}_{24}\left[\varepsilon_{\mathrm{t}} / \mathrm{h}_{\mathrm{t}}\right]^{2} \\
\mathrm{p} \text { value }\end{array}$ & $\begin{array}{l}18.9830 \\
0.7530\end{array}$ & $\begin{array}{l}16.4890 \\
0.8700\end{array}$ & $\begin{array}{l}13.4320 \\
0.9580\end{array}$ & $\begin{array}{l}18.0450 \\
0.8010\end{array}$ & $\begin{array}{l}8.5532 \\
0.9980\end{array}$ \\
\hline $\begin{array}{c}\mathrm{Q}_{36}\left[\varepsilon_{\mathrm{t}} / \mathrm{h}_{\mathrm{t}}\right]^{2} \\
\mathrm{p} \text { value }\end{array}$ & $\begin{array}{l}24.2130 \\
0.9330\end{array}$ & $\begin{array}{l}22.1680 \\
0.9660\end{array}$ & $\begin{array}{l}24.6400 \\
0.9240\end{array}$ & $\begin{array}{l}22.2340 \\
0.9650\end{array}$ & $\begin{array}{l}12.3240 \\
1.0000\end{array}$ \\
\hline $\begin{array}{l}\text { Jarque-Bera } \\
\text { p value }\end{array}$ & $\begin{array}{l}205.7381 \\
0.0000\end{array}$ & $\begin{array}{l}115.4738 \\
0.0000\end{array}$ & $\begin{array}{l}11.4972 \\
0.0032\end{array}$ & $\begin{array}{l}22.3652 \\
0.0000\end{array}$ & $\begin{array}{l}146.0171 \\
0.0000\end{array}$ \\
\hline
\end{tabular}


Table 4: MA(1)-GARCH(1,1) in mean only

\begin{tabular}{|c|c|c|c|c|c|}
\hline & $\begin{array}{l}9 / 1 / 95 \text { to } \\
12 / 31 / 02 \\
\end{array}$ & $\begin{array}{l}9 / 1 / 95 \text { to } \\
10 / 28 / 97 \\
\end{array}$ & $\begin{array}{l}10 / 29 / 97 \text { to } \\
8 / 19 / 98\end{array}$ & $\begin{array}{l}8 / 20 / 98 \text { to } \\
12 / 30 / 99\end{array}$ & $\begin{array}{l}12 / 31 / 99 \text { to } \\
12 / 31 / 02\end{array}$ \\
\hline \multicolumn{6}{|l|}{ Mean equation } \\
\hline$\theta_{0}$ & $\begin{array}{l}0.1251 \\
(0.0785)\end{array}$ & $\begin{array}{l}0.2030 \\
(0.1454)\end{array}$ & $\begin{array}{l}-0.5192 \\
(0.4046)\end{array}$ & $\begin{array}{l}0.0039 \\
(0.3018)\end{array}$ & $\begin{array}{l}0.0523 \\
(0.1394)\end{array}$ \\
\hline$\theta_{1}$ & $\begin{array}{l}0.1536 \\
(0.0262)\end{array}$ & $\begin{array}{l}0.2885 \\
(0.0567)\end{array}$ & $\begin{array}{l}0.1177 \\
(0.0743)\end{array}$ & $\begin{array}{l}0.1880 \\
(0.0559)\end{array}$ & $\begin{array}{l}0.0624 \\
(0.0384)\end{array}$ \\
\hline$\delta$ & $\begin{array}{l}0.0025 \\
(0.0092)\end{array}$ & $\begin{array}{l}-0.0020 \\
(0.0268)\end{array}$ & $\begin{array}{l}0.0113 \\
(0.0224)\end{array}$ & $\begin{array}{l}0.0105 \\
(0.0224)\end{array}$ & $\begin{array}{l}0.0234 \\
(0.0256)\end{array}$ \\
\hline \multicolumn{6}{|c|}{ Variance equation } \\
\hline$\omega$ & $\begin{array}{l}0.5654 \\
(0.1306)\end{array}$ & $\begin{array}{l}0.5303 \\
(0.3503)\end{array}$ & $\begin{array}{l}1.0854 \\
(0.6576)\end{array}$ & $\begin{array}{l}2.1949 \\
(1.0642)\end{array}$ & $\begin{array}{l}0.2009 \\
(0.0928)\end{array}$ \\
\hline$\alpha_{1}$ & $\begin{array}{l}0.2282 \\
(0.0416)\end{array}$ & $\begin{array}{l}0.3095 \\
(0.1122)\end{array}$ & $\begin{array}{l}0.2643 \\
(0.1147)\end{array}$ & $\begin{array}{l}0.2922 \\
(0.0749)\end{array}$ & $\begin{array}{l}0.1113 \\
(0.0310)\end{array}$ \\
\hline$\beta_{1}$ & $\begin{array}{l}0.7457 \\
(0.0410)\end{array}$ & $\begin{array}{l}0.6739 \\
(0.1238)\end{array}$ & $\begin{array}{l}0.7210 \\
(0.0967)\end{array}$ & $\begin{array}{l}0.5793 \\
(0.1117)\end{array}$ & $\begin{array}{l}0.8558 \\
(0.0352)\end{array}$ \\
\hline$\alpha_{1}+\beta_{1}$ & $\begin{array}{l}0.9739 \\
(0.0200)\end{array}$ & $\begin{array}{l}0.9834 \\
(0.0598)\end{array}$ & $\begin{array}{l}0.9853 \\
(0.0477)\end{array}$ & $\begin{array}{l}0.8715 \\
(0.0947)\end{array}$ & $\begin{array}{l}0.9671 \\
(0.0173)\end{array}$ \\
\hline \multicolumn{6}{|l|}{ Statistics } \\
\hline Log-likelihood & -4477.1100 & -1247.4060 & -566.6967 & -923.2238 & -1718.3920 \\
\hline AIC & 4.8916 & 4.6682 & 5.7270 & 5.4025 & 4.5861 \\
\hline SIC & 4.9096 & 4.7161 & 5.8259 & 5.4695 & 4.6230 \\
\hline $\begin{array}{c}\mathrm{Q}_{12}\left[\varepsilon_{\mathrm{t}} / \mathrm{h}_{\mathrm{t}}\right] \\
\mathrm{p} \text { value }\end{array}$ & $\begin{array}{l}37.5530 \\
0.0000\end{array}$ & $\begin{array}{l}19.4020 \\
0.0540\end{array}$ & $\begin{array}{l}13.8310 \\
0.2420\end{array}$ & $\begin{array}{l}9.3690 \\
0.5880\end{array}$ & $\begin{array}{l}10.9780 \\
0.4450\end{array}$ \\
\hline $\begin{array}{c}\mathrm{Q}_{24}\left[\varepsilon_{\mathrm{t}} / \mathrm{h}_{\mathrm{t}}\right] \\
\mathrm{p} \text { value }\end{array}$ & $\begin{array}{l}47.2570 \\
0.0020\end{array}$ & $\begin{array}{l}24.5080 \\
0.3760\end{array}$ & $\begin{array}{l}26.6110 \\
0.2730\end{array}$ & $\begin{array}{l}23.6950 \\
0.4210\end{array}$ & $\begin{array}{l}23.4260 \\
0.4360\end{array}$ \\
\hline $\begin{array}{c}\mathrm{Q}_{36}\left[\varepsilon_{\mathrm{t}} / \mathrm{h}_{\mathrm{t}}\right] \\
\mathrm{p} \text { value }\end{array}$ & $\begin{array}{l}58.5050 \\
0.0080\end{array}$ & $\begin{array}{l}37.4160 \\
0.3590\end{array}$ & $\begin{array}{l}44.2470 \\
0.1360\end{array}$ & $\begin{array}{l}35.9050 \\
0.4260\end{array}$ & $\begin{array}{l}33.2680 \\
0.5520\end{array}$ \\
\hline $\begin{array}{c}\mathrm{Q}_{12}\left[\varepsilon_{\mathrm{t}} / \mathrm{h}_{\mathrm{t}}\right]^{2} \\
\mathrm{p} \text { value }\end{array}$ & $\begin{array}{l}12.5500 \\
0.4830\end{array}$ & $\begin{array}{l}6.4251 \\
0.8440\end{array}$ & $\begin{array}{l}8.7571 \\
0.6440\end{array}$ & $\begin{array}{l}8.0496 \\
0.7090\end{array}$ & $\begin{array}{l}2.5495 \\
0.9950\end{array}$ \\
\hline $\begin{array}{c}\mathrm{Q}_{24}\left[\varepsilon_{\mathrm{t}} / \mathrm{h}_{\mathrm{t}}\right]^{2} \\
\mathrm{p} \text { value }\end{array}$ & $\begin{array}{l}19.0620 \\
0.6980\end{array}$ & $\begin{array}{l}16.3900 \\
0.8380\end{array}$ & $\begin{array}{l}13.6230 \\
0.9370\end{array}$ & $\begin{array}{l}19.3550 \\
0.6800\end{array}$ & $\begin{array}{l}8.4765 \\
0.9970\end{array}$ \\
\hline $\begin{array}{c}\mathrm{Q}_{36}\left[\varepsilon_{\mathrm{t}} / \mathrm{h}_{\mathrm{t}}\right]^{2} \\
\mathrm{p} \text { value }\end{array}$ & $\begin{array}{l}24.1040 \\
0.9170\end{array}$ & $\begin{array}{l}22.1220 \\
0.9550\end{array}$ & $\begin{array}{l}24.2520 \\
0.9140\end{array}$ & $\begin{array}{l}23.3430 \\
0.9340\end{array}$ & $\begin{array}{l}12.1960 \\
1.0000\end{array}$ \\
\hline $\begin{array}{l}\text { Jarque-Bera } \\
\text { p value }\end{array}$ & $\begin{array}{l}211.5154 \\
0.0000\end{array}$ & $\begin{array}{l}118.8898 \\
0.0000\end{array}$ & $\begin{array}{l}12.5999 \\
0.0018\end{array}$ & $\begin{array}{l}22.2046 \\
0.0000\end{array}$ & $\begin{array}{l}148.8526 \\
0.0000\end{array}$ \\
\hline
\end{tabular}


Table 5: $\operatorname{AR}(1)-G A R C H(1,1)$ in mean with volume

\begin{tabular}{|c|c|c|c|c|c|}
\hline & $\begin{array}{l}9 / 1 / 95 \text { to } \\
12 / 31 / 02 \\
\end{array}$ & $\begin{array}{l}9 / 1 / 95 \text { to } \\
10 / 28 / 97 \\
\end{array}$ & $\begin{array}{l}10 / 29 / 97 \text { to } \\
8 / 19 / 98\end{array}$ & $\begin{array}{l}8 / 20 / 98 \text { to } \\
12 / 30 / 99\end{array}$ & $\begin{array}{l}12 / 31 / 99 \text { to } \\
12 / 31 / 02\end{array}$ \\
\hline \multicolumn{6}{|l|}{ Mean equation } \\
\hline$\phi_{0}$ & $\begin{array}{l}-0.0382 \\
(0.0542)\end{array}$ & $\begin{array}{l}-0.0341 \\
(0.0877)\end{array}$ & $\begin{array}{l}-1.3055 \\
(0.4040)\end{array}$ & $\begin{array}{l}-1.3002 \\
(0.3382)\end{array}$ & $\begin{array}{l}-0.4323 \\
(0.1950)\end{array}$ \\
\hline$\phi_{1}$ & $\begin{array}{l}0.1298 \\
(0.0256)\end{array}$ & $\begin{array}{l}0.2051 \\
(0.0527)\end{array}$ & $\begin{array}{l}0.0981 \\
(0.0642)\end{array}$ & $\begin{array}{l}0.1845 \\
(0.0657)\end{array}$ & $\begin{array}{l}0.0545 \\
(0.0381)\end{array}$ \\
\hline$\delta$ & $\begin{array}{l}0.0213 \\
(0.0073)\end{array}$ & $\begin{array}{l}0.0360 \\
(0.0162)\end{array}$ & $\begin{array}{l}0.0564 \\
(0.0245)\end{array}$ & $\begin{array}{l}0.1144 \\
(0.0356)\end{array}$ & $\begin{array}{l}0.0875 \\
(0.0382)\end{array}$ \\
\hline \multicolumn{6}{|c|}{ Variance equation } \\
\hline$\omega$ & $\begin{array}{l}0.6643 \\
(0.1271)\end{array}$ & $\begin{array}{l}2.0113 \\
(0.4406)\end{array}$ & $\begin{array}{l}5.2114 \\
(1.0024)\end{array}$ & $\begin{array}{l}4.2609 \\
(1.0975)\end{array}$ & $\begin{array}{l}2.0608 \\
(0.5689)\end{array}$ \\
\hline$\alpha_{1}$ & $\begin{array}{l}0.3133 \\
(0.0426)\end{array}$ & $\begin{array}{l}0.4365 \\
(0.0652)\end{array}$ & $\begin{array}{l}0.3300 \\
(0.0736)\end{array}$ & $\begin{array}{l}0.1350 \\
(0.0597)\end{array}$ & $\begin{array}{l}0.2096 \\
(0.0556)\end{array}$ \\
\hline$\beta_{1}$ & $\begin{array}{l}0.6392 \\
(0.0400)\end{array}$ & $\begin{array}{l}0.3595 \\
(0.1162)\end{array}$ & $\begin{array}{l}0.4087 \\
(0.0897)\end{array}$ & $\begin{array}{l}0.5247 \\
(0.1280)\end{array}$ & $\begin{array}{l}0.4053 \\
(0.1430)\end{array}$ \\
\hline$\gamma$ & $\begin{array}{l}0.0144 \\
(0.0017)\end{array}$ & $\begin{array}{l}0.0200 \\
(0.0016)\end{array}$ & $\begin{array}{l}0.1016 \\
(0.0190)\end{array}$ & $\begin{array}{l}0.0675 \\
(0.0075)\end{array}$ & $\begin{array}{l}0.0275 \\
(0.0023)\end{array}$ \\
\hline$\alpha_{1}+\beta_{1}$ & $\begin{array}{l}0.9524 \\
(0.0240)\end{array}$ & $\begin{array}{l}0.7960 \\
(0.0955)\end{array}$ & $\begin{array}{l}0.7387 \\
(0.0817)\end{array}$ & $\begin{array}{l}0.6597 \\
(0.0813)\end{array}$ & $\begin{array}{l}0.6153 \\
(0.1164)\end{array}$ \\
\hline \multicolumn{6}{|l|}{ Statistics } \\
\hline Log-likelihood & -4412.7390 & -1232.5650 & -556.4901 & -903.5032 & -1698.3490 \\
\hline AIC & 4.8224 & 4.6166 & 5.6349 & 5.2936 & 4.5355 \\
\hline SIC & 4.8435 & 4.6725 & 5.7503 & 5.3718 & 4.5785 \\
\hline $\begin{array}{c}\mathrm{Q}_{12}\left[\varepsilon_{\mathrm{t}} / \mathrm{h}_{\mathrm{t}}\right] \\
\mathrm{p} \text { value }\end{array}$ & $\begin{array}{l}37.8370 \\
0.0000\end{array}$ & $\begin{array}{l}15.7420 \\
0.2030\end{array}$ & $\begin{array}{l}17.5930 \\
0.1290\end{array}$ & $\begin{array}{l}9.2668 \\
0.6800\end{array}$ & $\begin{array}{l}8.3106 \\
0.7600\end{array}$ \\
\hline $\begin{array}{c}\mathrm{Q}_{24}\left[\varepsilon_{\mathrm{t}} / \mathrm{h}_{\mathrm{t}}\right] \\
\mathrm{p} \text { value }\end{array}$ & $\begin{array}{l}48.3630 \\
0.0020\end{array}$ & $\begin{array}{l}23.1600 \\
0.4660\end{array}$ & $\begin{array}{l}30.6640 \\
0.1640\end{array}$ & $\begin{array}{l}18.0450 \\
0.8010\end{array}$ & $\begin{array}{l}24.1580 \\
0.4530\end{array}$ \\
\hline $\begin{array}{c}\mathrm{Q}_{36}\left[\varepsilon_{\mathrm{t}} / \mathrm{h}_{\mathrm{t}}\right] \\
\mathrm{p} \text { value }\end{array}$ & $\begin{array}{l}60.5550 \\
0.0060\end{array}$ & $\begin{array}{l}41.9340 \\
0.2290\end{array}$ & $\begin{array}{l}47.0680 \\
0.1030\end{array}$ & $\begin{array}{l}30.1400 \\
0.7430\end{array}$ & $\begin{array}{l}34.3970 \\
0.5450\end{array}$ \\
\hline $\begin{array}{c}\mathrm{Q}_{12}\left[\varepsilon_{\mathrm{t}} / \mathrm{h}_{\mathrm{t}}\right]^{2} \\
\mathrm{p} \text { value }\end{array}$ & $\begin{array}{l}13.5860 \\
0.3280\end{array}$ & $\begin{array}{l}19.2580 \\
0.0820\end{array}$ & $\begin{array}{l}12.7950 \\
0.3840\end{array}$ & $\begin{array}{l}9.7490 \\
0.6380\end{array}$ & $\begin{array}{l}15.3760 \\
0.2220\end{array}$ \\
\hline $\begin{array}{c}\mathrm{Q}_{24}\left[\varepsilon_{\mathrm{t}} / \mathrm{h}_{\mathrm{t}}\right]^{2} \\
\mathrm{p} \text { value }\end{array}$ & $\begin{array}{l}21.5480 \\
0.6060\end{array}$ & $\begin{array}{l}27.5970 \\
0.2770\end{array}$ & $\begin{array}{l}18.6000 \\
0.7730\end{array}$ & $\begin{array}{l}37.6600 \\
0.0380\end{array}$ & $\begin{array}{l}26.4110 \\
0.3330\end{array}$ \\
\hline $\begin{array}{c}\mathrm{Q}_{36}\left[\varepsilon_{\mathrm{t}} / \mathrm{h}_{\mathrm{t}}\right]^{2} \\
\mathrm{p} \text { value }\end{array}$ & $\begin{array}{l}27.9400 \\
0.8290\end{array}$ & $\begin{array}{l}36.0010 \\
0.4690\end{array}$ & $\begin{array}{l}27.7510 \\
0.8360\end{array}$ & $\begin{array}{l}41.0540 \\
0.2590\end{array}$ & $\begin{array}{l}32.3330 \\
0.6440\end{array}$ \\
\hline $\begin{array}{l}\text { Jarque-Bera } \\
\text { p value }\end{array}$ & $\begin{array}{l}182.5831 \\
0.0000\end{array}$ & $\begin{array}{l}252.2015 \\
0.0000\end{array}$ & $\begin{array}{l}7.4913 \\
0.0236\end{array}$ & $\begin{array}{l}89.6675 \\
0.0000\end{array}$ & $\begin{array}{l}234.9320 \\
0.0000\end{array}$ \\
\hline
\end{tabular}


Table 6. MA(1)-GARCH(1,1) in mean with volume

\begin{tabular}{|c|c|c|c|c|c|}
\hline & $\begin{array}{l}9 / 1 / 95 \text { to } \\
12 / 31 / 02 \\
\end{array}$ & $\begin{array}{l}9 / 1 / 95 \text { to } \\
10 / 28 / 97 \\
\end{array}$ & $\begin{array}{l}10 / 29 / 97 \text { to } \\
8 / 19 / 98 \\
\end{array}$ & $\begin{array}{l}8 / 20 / 98 \text { to } \\
12 / 30 / 99 \\
\end{array}$ & $\begin{array}{l}12 / 31 / 99 \text { to } \\
12 / 31 / 02\end{array}$ \\
\hline \multicolumn{6}{|l|}{ Mean equation } \\
\hline$\theta_{0}$ & $\begin{array}{l}-0.0242 \\
(0.0577)\end{array}$ & $\begin{array}{l}0.0491 \\
(0.0830)\end{array}$ & $\begin{array}{l}-1.3510 \\
(0.4280)\end{array}$ & $\begin{array}{l}-1.0474 \\
(0.2616)\end{array}$ & $\begin{array}{l}-0.3648 \\
(0.1731)\end{array}$ \\
\hline$\theta_{1}$ & $\begin{array}{l}0.1236 \\
(0.0253)\end{array}$ & $\begin{array}{l}0.2683 \\
(0.0526)\end{array}$ & $\begin{array}{l}0.1210 \\
(0.0668)\end{array}$ & $\begin{array}{l}0.1631 \\
(0.0559)\end{array}$ & $\begin{array}{l}0.0689 \\
(0.0369)\end{array}$ \\
\hline$\delta$ & $\begin{array}{l}0.0233 \\
(0.0074) \\
\end{array}$ & $\begin{array}{l}0.0408 \\
(0.0179) \\
\end{array}$ & $\begin{array}{l}0.0599 \\
(0.0259) \\
\end{array}$ & $\begin{array}{l}0.0957 \\
(0.0302) \\
\end{array}$ & $\begin{array}{l}0.0729 \\
(0.0342) \\
\end{array}$ \\
\hline \multicolumn{6}{|c|}{ Variance equation } \\
\hline$\omega$ & $\begin{array}{l}0.6874 \\
(0.1302)\end{array}$ & $\begin{array}{l}2.1437 \\
(0.4193)\end{array}$ & $\begin{array}{l}4.9319 \\
(0.9970)\end{array}$ & $\begin{array}{l}4.3501 \\
(1.1606)\end{array}$ & $\begin{array}{l}1.9367 \\
(0.5207)\end{array}$ \\
\hline$\alpha_{1}$ & $\begin{array}{l}0.3214 \\
(0.0431)\end{array}$ & $\begin{array}{l}0.4478 \\
(0.0629)\end{array}$ & $\begin{array}{l}0.3160 \\
(0.0717)\end{array}$ & $\begin{array}{l}0.1537 \\
(0.0684)\end{array}$ & $\begin{array}{l}0.1554 \\
(0.0430)\end{array}$ \\
\hline$\beta_{1}$ & $\begin{array}{l}0.6299 \\
(0.0401)\end{array}$ & $\begin{array}{l}0.3370 \\
(0.1103)\end{array}$ & $\begin{array}{l}0.4326 \\
(0.0907)\end{array}$ & $\begin{array}{l}0.5062 \\
(0.1409)\end{array}$ & $\begin{array}{l}0.5134 \\
(0.1165)\end{array}$ \\
\hline$\gamma$ & $\begin{array}{l}0.0147 \\
(0.0017)\end{array}$ & $\begin{array}{l}0.0206 \\
(0.0017)\end{array}$ & $\begin{array}{l}0.0987 \\
(0.0195)\end{array}$ & $\begin{array}{l}0.0663 \\
(0.0076)\end{array}$ & $\begin{array}{l}0.0306 \\
(0.0019)\end{array}$ \\
\hline$\alpha_{1}+\beta_{1}$ & $\begin{array}{l}0.9513 \\
(0.0251)\end{array}$ & $\begin{array}{l}0.7848 \\
(0.0930)\end{array}$ & $\begin{array}{l}0.7486 \\
(0.0800)\end{array}$ & $\begin{array}{l}0.6599 \\
(0.0906)\end{array}$ & $\begin{array}{l}0.6689 \\
(0.0951)\end{array}$ \\
\hline \multicolumn{6}{|l|}{ Statistics } \\
\hline Log-likelihood & -4413.2920 & -1230.2720 & -555.9874 & -904.0456 & -1695.5920 \\
\hline AIC & 4.8230 & 4.6081 & 5.6299 & 5.2968 & 4.5282 \\
\hline SIC & 4.8441 & 4.6640 & 5.7453 & 5.3749 & 4.5712 \\
\hline $\begin{array}{c}\mathrm{Q}_{12}\left[\varepsilon_{\mathrm{t}} / \mathrm{h}_{\mathrm{t}}\right] \\
\mathrm{p} \text { value }\end{array}$ & $\begin{array}{l}43.1840 \\
0.0000\end{array}$ & $\begin{array}{l}11.3240 \\
0.4170\end{array}$ & $\begin{array}{l}17.6070 \\
0.0910\end{array}$ & $\begin{array}{l}12.4210 \\
0.3330\end{array}$ & $\begin{array}{l}9.2616 \\
0.5980\end{array}$ \\
\hline $\begin{array}{c}\mathrm{Q}_{24}\left[\varepsilon_{\mathrm{t}} / \mathrm{h}_{\mathrm{t}}\right] \\
\mathrm{p} \text { value }\end{array}$ & $\begin{array}{l}53.6280 \\
0.0000\end{array}$ & $\begin{array}{l}19.4040 \\
0.6780\end{array}$ & $\begin{array}{l}30.0710 \\
0.1470\end{array}$ & $\begin{array}{l}22.1490 \\
0.5110\end{array}$ & $\begin{array}{l}25.3250 \\
0.3340\end{array}$ \\
\hline $\begin{array}{c}\mathrm{Q}_{36}\left[\varepsilon_{\mathrm{t}} / \mathrm{h}_{\mathrm{t}}\right] \\
\mathrm{p} \text { value }\end{array}$ & $\begin{array}{l}65.6830 \\
0.0001\end{array}$ & $\begin{array}{l}37.0110 \\
0.3760\end{array}$ & $\begin{array}{l}45.9590 \\
0.1020\end{array}$ & $\begin{array}{l}33.9960 \\
0.5160\end{array}$ & $\begin{array}{l}35.1150 \\
0.4630\end{array}$ \\
\hline $\begin{array}{c}\mathrm{Q}_{12}\left[\varepsilon_{\mathrm{t}} / \mathrm{h}_{\mathrm{t}}\right]^{2} \\
\mathrm{p} \text { value }\end{array}$ & $\begin{array}{l}14.2560 \\
0.2190\end{array}$ & $\begin{array}{l}25.7270 \\
0.0070\end{array}$ & $\begin{array}{l}13.4830 \\
0.2630\end{array}$ & $\begin{array}{l}10.9400 \\
0.4480\end{array}$ & $\begin{array}{l}16.8450 \\
0.2060\end{array}$ \\
\hline $\begin{array}{c}\mathrm{Q}_{24}\left[\varepsilon_{\mathrm{t}} / \mathrm{h}_{\mathrm{t}}\right]^{2} \\
\mathrm{p} \text { value }\end{array}$ & $\begin{array}{l}22.1010 \\
0.5140\end{array}$ & $\begin{array}{l}35.4960 \\
0.0460\end{array}$ & $\begin{array}{l}18.7630 \\
0.7150\end{array}$ & $\begin{array}{l}37.4710 \\
0.0290\end{array}$ & $\begin{array}{l}26.0500 \\
0.2980\end{array}$ \\
\hline $\begin{array}{c}\mathrm{Q}_{36}\left[\varepsilon_{\mathrm{t}} / \mathrm{h}_{\mathrm{t}}\right]^{2} \\
\mathrm{p} \text { value }\end{array}$ & $\begin{array}{l}28.2450 \\
0.7840\end{array}$ & $\begin{array}{l}43.9040 \\
0.1440\end{array}$ & $\begin{array}{l}27.7300 \\
0.8040\end{array}$ & $\begin{array}{l}40.4890 \\
0.2410\end{array}$ & $\begin{array}{l}32.1590 \\
0.6060\end{array}$ \\
\hline $\begin{array}{l}\text { Jarque-Bera } \\
\text { p value }\end{array}$ & $\begin{array}{l}184.8198 \\
0.0000\end{array}$ & $\begin{array}{l}270.3201 \\
0.0000\end{array}$ & $\begin{array}{l}6.6769 \\
0.0355\end{array}$ & $\begin{array}{l}81.9370 \\
0.0000\end{array}$ & $\begin{array}{l}288.2924 \\
0.0000\end{array}$ \\
\hline
\end{tabular}


Table 7. AR(1)-GARCH(1,1) in mean with decomposed volume

\begin{tabular}{|c|c|c|c|c|c|}
\hline & $\begin{array}{l}\text { 9/1/95 to } \\
12 / 31 / 02 \\
\end{array}$ & $\begin{array}{l}9 / 1 / 95 \text { to } \\
10 / 28 / 97 \\
\end{array}$ & $\begin{array}{l}10 / 29 / 97 \text { to } \\
8 / 19 / 98\end{array}$ & $\begin{array}{l}8 / 20 / 98 \text { to } \\
12 / 30 / 99 \\
\end{array}$ & $\begin{array}{l}12 / 31 / 99 \text { to } \\
12 / 31 / 02\end{array}$ \\
\hline \multicolumn{6}{|l|}{ Mean equation } \\
\hline$\phi_{0}$ & $\begin{array}{l}-0.2054 \\
(0.0352)\end{array}$ & $\begin{array}{l}-0.0631 \\
(0.0778)\end{array}$ & $\begin{array}{l}-1.1327 \\
(0.3531)\end{array}$ & $\begin{array}{l}-0.8020 \\
(0.0996)\end{array}$ & $\begin{array}{l}-0.2963 \\
(0.1458)\end{array}$ \\
\hline$\phi_{1}$ & $\begin{array}{l}0.1261 \\
(0.0269)\end{array}$ & $\begin{array}{l}0.1972 \\
(0.0524)\end{array}$ & $\begin{array}{l}0.0869 \\
(0.0644)\end{array}$ & $\begin{array}{l}0.1609 \\
(0.0557)\end{array}$ & $\begin{array}{l}0.0414 \\
(0.0384)\end{array}$ \\
\hline$\delta$ & $\begin{array}{l}0.0372 \\
(0.0072)\end{array}$ & $\begin{array}{l}0.0356 \\
(0.0155)\end{array}$ & $\begin{array}{l}0.0509 \\
(0.0216)\end{array}$ & $\begin{array}{l}0.0743 \\
(0.0205)\end{array}$ & $\begin{array}{l}0.0688 \\
(0.0280)\end{array}$ \\
\hline \multicolumn{6}{|c|}{ Variance equation } \\
\hline$\omega$ & $\begin{array}{l}0.9163 \\
(0.1807)\end{array}$ & $\begin{array}{l}1.9314 \\
(0.5923)\end{array}$ & $\begin{array}{l}3.1329 \\
(1.2186)\end{array}$ & $\begin{array}{l}2.5514 \\
(0.3963)\end{array}$ & $\begin{array}{l}2.3952 \\
(0.6942)\end{array}$ \\
\hline$\alpha_{1}$ & $\begin{array}{l}0.3532 \\
(0.0434)\end{array}$ & $\begin{array}{l}0.4402 \\
(0.0776)\end{array}$ & $\begin{array}{l}0.3467 \\
(0.0714)\end{array}$ & $\begin{array}{l}0.1740 \\
(0.0559)\end{array}$ & $\begin{array}{l}0.2349 \\
(0.0587)\end{array}$ \\
\hline$\beta_{1}$ & $\begin{array}{l}0.4801 \\
(0.0406)\end{array}$ & $\begin{array}{l}0.3786 \\
(0.1199)\end{array}$ & $\begin{array}{l}0.4270 \\
(0.0808)\end{array}$ & $\begin{array}{l}0.4900 \\
(0.0620)\end{array}$ & $\begin{array}{l}0.2703 \\
(0.1387)\end{array}$ \\
\hline$\gamma_{1}$ & $\begin{array}{l}0.0528 \\
(0.0069)\end{array}$ & $\begin{array}{l}0.0235 \\
(0.0121)\end{array}$ & $\begin{array}{l}0.1751 \\
(0.0463)\end{array}$ & $\begin{array}{l}0.1414 \\
(0.0342)\end{array}$ & $\begin{array}{l}0.0619 \\
(0.0147)\end{array}$ \\
\hline$\gamma_{2}$ & $\begin{array}{l}0.0159 \\
(0.0013)\end{array}$ & $\begin{array}{l}0.0203 \\
(0.0020)\end{array}$ & $\begin{array}{l}0.0755 \\
(0.0244)\end{array}$ & $\begin{array}{l}0.0546 \\
(0.0071)\end{array}$ & $\begin{array}{l}0.0261 \\
(0.0029)\end{array}$ \\
\hline$\alpha_{1}+\beta_{1}$ & $\begin{array}{l}0.8333 \\
(0.0361)\end{array}$ & $\begin{array}{l}0.8188 \\
(0.0899)\end{array}$ & $\begin{array}{l}0.7736 \\
(0.0766)\end{array}$ & $\begin{array}{l}0.6640 \\
(0.0504)\end{array}$ & $\begin{array}{l}0.5053 \\
(0.1287)\end{array}$ \\
\hline$\gamma_{1}-\gamma_{2}$ & $\begin{array}{l}0.0369 \\
(0.0076)\end{array}$ & $\begin{array}{l}0.0032 \\
(0.0133)\end{array}$ & $\begin{array}{l}0.0996 \\
(0.0585)\end{array}$ & $\begin{array}{l}0.0868 \\
(0.0362)\end{array}$ & $\begin{array}{l}0.0358 \\
(0.0163)\end{array}$ \\
\hline \multicolumn{6}{|l|}{$\underline{\text { Statistics }}$} \\
\hline Log-likelihood & -4398.0660 & -1231.6610 & -556.0643 & -893.3106 & -1702.4070 \\
\hline AIC & 4.8075 & 4.6170 & 5.6406 & 5.2402 & 4.5490 \\
\hline SIC & 4.8316 & 4.6808 & 5.7726 & 5.3295 & 4.5981 \\
\hline $\begin{array}{c}\mathrm{Q}_{12}\left[\varepsilon_{\mathrm{t}} / \mathrm{h}_{\mathrm{t}}\right] \\
\mathrm{p} \text { value }\end{array}$ & $\begin{array}{l}38.5810 \\
0.0000\end{array}$ & $\begin{array}{l}16.2810 \\
0.1790\end{array}$ & $\begin{array}{l}18.4990 \\
0.1010\end{array}$ & $\begin{array}{l}10.8480 \\
0.5420\end{array}$ & $\begin{array}{l}7.8484 \\
0.7970\end{array}$ \\
\hline $\begin{array}{c}\mathrm{Q}_{24}\left[\varepsilon_{\mathrm{t}} / \mathrm{h}_{\mathrm{t}}\right] \\
\mathrm{p} \text { value }\end{array}$ & $\begin{array}{l}50.7540 \\
0.0010\end{array}$ & $\begin{array}{l}24.5020 \\
0.4330\end{array}$ & $\begin{array}{l}30.0630 \\
0.1830\end{array}$ & $\begin{array}{l}19.6960 \\
0.7140\end{array}$ & $\begin{array}{l}24.4020 \\
0.4390\end{array}$ \\
\hline $\begin{array}{c}\mathrm{Q}_{36}\left[\varepsilon_{\mathrm{t}} / \mathrm{h}_{\mathrm{t}}\right] \\
\mathrm{p} \text { value }\end{array}$ & $\begin{array}{l}65.4330 \\
0.0020\end{array}$ & $\begin{array}{l}42.6980 \\
0.2050\end{array}$ & $\begin{array}{l}46.6760 \\
0.1100\end{array}$ & $\begin{array}{l}29.3960 \\
0.7740\end{array}$ & $\begin{array}{l}34.0080 \\
0.5640\end{array}$ \\
\hline $\begin{array}{c}\mathrm{Q}_{12}\left[\varepsilon_{\mathrm{t}} / \mathrm{h}_{\mathrm{t}}\right]^{2} \\
\mathrm{p} \text { value }\end{array}$ & $\begin{array}{l}33.6240 \\
0.0010\end{array}$ & $\begin{array}{l}18.4370 \\
0.1030\end{array}$ & $\begin{array}{l}14.1940 \\
0.2880\end{array}$ & $\begin{array}{l}9.9599 \\
0.6190\end{array}$ & $\begin{array}{l}20.5940 \\
0.0570\end{array}$ \\
\hline $\begin{array}{c}\mathrm{Q}_{24}\left[\varepsilon_{\mathrm{t}} / \mathrm{h}_{\mathrm{t}}\right]^{2} \\
\mathrm{p} \text { value }\end{array}$ & $\begin{array}{l}49.6170 \\
0.0020\end{array}$ & $\begin{array}{l}26.5470 \\
0.3260\end{array}$ & $\begin{array}{l}19.9010 \\
0.7020\end{array}$ & $\begin{array}{l}39.0820 \\
0.0270\end{array}$ & $\begin{array}{l}29.2750 \\
0.2100\end{array}$ \\
\hline $\begin{array}{c}\mathrm{Q}_{36}\left[\varepsilon_{\mathrm{t}} / \mathrm{h}_{\mathrm{t}}\right]^{2} \\
\mathrm{p} \text { value }\end{array}$ & $\begin{array}{l}65.5690 \\
0.0020\end{array}$ & $\begin{array}{l}34.9000 \\
0.5210\end{array}$ & $\begin{array}{l}29.1580 \\
0.7830\end{array}$ & $\begin{array}{l}42.5680 \\
0.2090\end{array}$ & $\begin{array}{l}36.0010 \\
0.4690\end{array}$ \\
\hline $\begin{array}{l}\text { Jarque-Bera } \\
\text { p value }\end{array}$ & $\begin{array}{l}365.0391 \\
0.0000\end{array}$ & $\begin{array}{l}241.2828 \\
0.0000\end{array}$ & $\begin{array}{l}8.7589 \\
0.0125\end{array}$ & $\begin{array}{l}64.8564 \\
0.0000\end{array}$ & $\begin{array}{l}390.8465 \\
0.0000\end{array}$ \\
\hline
\end{tabular}


Table 8: MA(1)-GARCH(1,1) in mean with decomposed volume

\begin{tabular}{|c|c|c|c|c|c|}
\hline & $\begin{array}{l}9 / 1 / 95 \text { to } \\
12 / 31 / 02 \\
\end{array}$ & $\begin{array}{l}9 / 1 / 95 \text { to } \\
10 / 28 / 97 \\
\end{array}$ & $\begin{array}{l}10 / 29 / 97 \text { to } \\
8 / 19 / 98\end{array}$ & $\begin{array}{l}8 / 20 / 98 \text { to } \\
12 / 30 / 99 \\
\end{array}$ & $\begin{array}{l}12 / 31 / 99 \text { to } \\
12 / 31 / 02\end{array}$ \\
\hline \multicolumn{6}{|l|}{ Mean equation } \\
\hline$\theta_{0}$ & $\begin{array}{l}-0.2172 \\
(0.0322)\end{array}$ & $\begin{array}{l}-0.0667 \\
(0.2009)\end{array}$ & $\begin{array}{l}-1.1681 \\
(0.3744)\end{array}$ & $\begin{array}{l}-0.7775 \\
(0.0773)\end{array}$ & $\begin{array}{l}-0.3138 \\
(0.2046)\end{array}$ \\
\hline$\theta_{1}$ & $\begin{array}{l}0.1105 \\
(0.0246)\end{array}$ & $\begin{array}{l}0.2974 \\
(0.0536)\end{array}$ & $\begin{array}{l}0.1118 \\
(0.0667)\end{array}$ & $\begin{array}{l}0.1372 \\
(0.0464)\end{array}$ & $\begin{array}{l}0.0275 \\
(0.0388)\end{array}$ \\
\hline$\delta$ & $\begin{array}{l}0.0443 \\
(0.0070)\end{array}$ & $\begin{array}{l}0.0374 \\
(0.0263)\end{array}$ & $\begin{array}{l}0.0540 \\
(0.0226)\end{array}$ & $\begin{array}{l}0.0713 \\
(0.0188)\end{array}$ & $\begin{array}{l}0.0748 \\
(0.0356)\end{array}$ \\
\hline \multicolumn{6}{|c|}{ Variance equation } \\
\hline$\omega$ & $\begin{array}{l}0.4294 \\
(0.1232)\end{array}$ & $\begin{array}{l}1.6328 \\
(0.2599)\end{array}$ & $\begin{array}{l}2.9999 \\
(1.2472)\end{array}$ & $\begin{array}{l}2.7313 \\
(0.4790)\end{array}$ & $\begin{array}{l}2.2197 \\
(0.6411)\end{array}$ \\
\hline$\alpha_{1}$ & $\begin{array}{l}0.3464 \\
(0.0452)\end{array}$ & $\begin{array}{l}0.4302 \\
(0.0589)\end{array}$ & $\begin{array}{l}0.3346 \\
(0.0699)\end{array}$ & $\begin{array}{l}0.2088 \\
(0.0628)\end{array}$ & $\begin{array}{l}0.2365 \\
(0.0597)\end{array}$ \\
\hline$\beta_{1}$ & $\begin{array}{l}0.5142 \\
(0.0356)\end{array}$ & $\begin{array}{l}0.3650 \\
(0.0649)\end{array}$ & $\begin{array}{l}0.4450 \\
(0.0821)\end{array}$ & $\begin{array}{l}0.4230 \\
(0.0792)\end{array}$ & $\begin{array}{l}0.2875 \\
(0.1314)\end{array}$ \\
\hline$\gamma_{1}$ & $\begin{array}{l}0.0538 \\
(0.0064)\end{array}$ & $\begin{array}{l}0.0357 \\
(0.0100)\end{array}$ & $\begin{array}{l}0.1687 \\
(0.0462)\end{array}$ & $\begin{array}{l}0.1567 \\
(0.0365)\end{array}$ & $\begin{array}{l}0.0617 \\
(0.0142)\end{array}$ \\
\hline$\gamma_{2}$ & $\begin{array}{l}0.0115 \\
(0.0015)\end{array}$ & $\begin{array}{l}0.0176 \\
(0.0020)\end{array}$ & $\begin{array}{l}0.0739 \\
(0.0255)\end{array}$ & $\begin{array}{l}0.0504 \\
(0.0087)\end{array}$ & $\begin{array}{l}0.0252 \\
(0.0030)\end{array}$ \\
\hline$\alpha_{1}+\beta_{1}$ & $\begin{array}{l}0.8606 \\
(0.0323)\end{array}$ & $\begin{array}{l}0.7953 \\
(0.0559)\end{array}$ & $\begin{array}{l}0.7796 \\
(0.0744)\end{array}$ & $\begin{array}{l}0.6317 \\
(0.0689)\end{array}$ & $\begin{array}{l}0.5241 \\
(0.1214)\end{array}$ \\
\hline$\gamma_{1}-\gamma_{2}$ & $\begin{array}{l}0.0423 \\
(0.0070) \\
\end{array}$ & $\begin{array}{l}0.0181 \\
(0.0095) \\
\end{array}$ & $\begin{array}{l}0.0948 \\
(0.0589) \\
\end{array}$ & $\begin{array}{l}0.1063 \\
(0.0390) \\
\end{array}$ & $\begin{array}{l}0.0365 \\
(0.0159)\end{array}$ \\
\hline \multicolumn{6}{|l|}{ Statistics } \\
\hline Log-likelihood & -4386.5080 & -1221.2310 & -555.5921 & -894.3767 & -1702.7260 \\
\hline AIC & 4.7949 & 4.5781 & 5.6359 & 5.2464 & 4.5498 \\
\hline SIC & 4.8189 & 4.6420 & 5.7679 & 5.3357 & 4.5990 \\
\hline $\begin{array}{c}\mathrm{Q}_{12}\left[\varepsilon_{\mathrm{t}} / \mathrm{h}_{\mathrm{t}}\right] \\
\mathrm{p} \text { value }\end{array}$ & $\begin{array}{l}48.5300 \\
0.0000\end{array}$ & $\begin{array}{l}8.3085 \\
0.6850\end{array}$ & $\begin{array}{l}18.2830 \\
0.0750\end{array}$ & $\begin{array}{l}14.5590 \\
0.2040\end{array}$ & $\begin{array}{l}7.4027 \\
0.7660\end{array}$ \\
\hline $\begin{array}{c}\mathrm{Q}_{24}\left[\varepsilon_{\mathrm{t}} / \mathrm{h}_{\mathrm{t}}\right] \\
\mathrm{p} \text { value }\end{array}$ & $\begin{array}{l}59.8730 \\
0.0000\end{array}$ & $\begin{array}{l}16.8300 \\
0.8180\end{array}$ & $\begin{array}{l}29.3600 \\
0.1690\end{array}$ & $\begin{array}{l}23.6590 \\
0.4230\end{array}$ & $\begin{array}{l}24.2000 \\
0.3930\end{array}$ \\
\hline $\begin{array}{c}\mathrm{Q}_{36}\left[\varepsilon_{\mathrm{t}} / \mathrm{h}_{\mathrm{t}}\right] \\
\mathrm{p} \text { value }\end{array}$ & $\begin{array}{l}74.5030 \\
0.0000\end{array}$ & $\begin{array}{l}33.9980 \\
0.5160\end{array}$ & $\begin{array}{l}45.5260 \\
0.1100\end{array}$ & $\begin{array}{l}32.3810 \\
0.5950\end{array}$ & $\begin{array}{l}33.9670 \\
0.5180\end{array}$ \\
\hline $\begin{array}{c}\mathrm{Q}_{12}\left[\varepsilon_{\mathrm{t}} / \mathrm{h}_{\mathrm{t}}\right]^{2} \\
\mathrm{p} \text { value }\end{array}$ & $\begin{array}{l}27.0990 \\
0.0040\end{array}$ & $\begin{array}{l}26.1290 \\
0.0060\end{array}$ & $\begin{array}{l}14.5110 \\
0.2060\end{array}$ & $\begin{array}{l}11.9890 \\
0.3640\end{array}$ & $\begin{array}{l}17.8240 \\
0.0860\end{array}$ \\
\hline $\begin{array}{c}\mathrm{Q}_{24}\left[\varepsilon_{\mathrm{t}} / \mathrm{h}_{\mathrm{t}}\right]^{2} \\
\mathrm{p} \text { value }\end{array}$ & $\begin{array}{l}38.3320 \\
0.0230\end{array}$ & $\begin{array}{l}34.7290 \\
0.0550\end{array}$ & $\begin{array}{l}19.8350 \\
0.6520\end{array}$ & $\begin{array}{l}39.7920 \\
0.0160\end{array}$ & $\begin{array}{l}26.2980 \\
0.2870\end{array}$ \\
\hline $\begin{array}{c}\mathrm{Q}_{36}\left[\varepsilon_{\mathrm{t}} / \mathrm{h}_{\mathrm{t}}\right]^{2} \\
\mathrm{p} \text { value }\end{array}$ & $\begin{array}{l}53.0540 \\
0.0260\end{array}$ & $\begin{array}{l}42.9350 \\
0.1680\end{array}$ & $\begin{array}{l}28.5770 \\
0.7700\end{array}$ & $\begin{array}{l}43.0100 \\
0.1660\end{array}$ & $\begin{array}{l}32.3940 \\
0.5950\end{array}$ \\
\hline $\begin{array}{c}\text { Jarque-Bera } \\
\text { p value }\end{array}$ & $\begin{array}{l}330.3281 \\
0.0000\end{array}$ & $\begin{array}{l}267.7297 \\
0.0000\end{array}$ & $\begin{array}{l}7.8055 \\
0.0202\end{array}$ & $\begin{array}{l}63.9780 \\
0.0000\end{array}$ & $\begin{array}{l}390.5394 \\
0.0000\end{array}$ \\
\hline
\end{tabular}

